vincing. Many observations reported by Derjaguin's school cannot be accounted for by the presence of minute amounts of impurities. Thus, density, viscosity, and heat conductivity of anomalous water as given in Issledovaniya $v$ Oblasti Poverkhnostnykh Sil (Studies on Surface Forces) ${ }^{2}$ deviate from the corresponding properties of ordinary water so much that no traces of impurities such as silica can explain the deviation. The protracted error immortalised in scores of publications can be due only to psychological (self-deception), not to chemical causes. The 'anomalous' water belongs to the category exemplified by the $\mathrm{N}$ rays of Blondlot ${ }^{3}$.

Yours faithfully,

JACOB J. BIKERMAN
15810 Van Aken Boulevard, Cleveland, Ohio 44120

'Derjaguin, B. V., and Churaev, N. V., Nature, 244, 430 (1973).

2 Issledovaniya $v$ Oblasti Poverkhnostnykh Sil (Studies on Surface Forces), 3, 31, 44 (Moscow, 1967).

${ }^{3}$ Blondlot, R., $N$ Rays (Longmans, Green and Co., London, 1905).

\title{
Obituary
}

\section{Professor N. K. Adam}

Neil Kensington Adam, FRS, who died in Southampton on July 19, was born 81 years ago, son of Dr James and Mrs Adela Marion Adam of Cambridge, and eldest of a family of three-his brother Arthur died in the 1914-18 war; his sister Barbara (Lady Wootton) survives him. After attending Winchester he went to Trinity, Cambridge, of which he later became a Fellow (1915-23). From Cambridge he undertook wartime chemical service with the Royal Naval Airships Service. But it was in 1921 that he commenced his distinguished researches into insoluble monomolecular surface films, being awarded in that year the Royal Society's Sorby Research Fellowship at Sheffield.

Inspired by Langmuir's earlier work, he (with G. Jessop) designed and built a series of surface pressure balances capable of measuring to about 0.01 dyne $\mathrm{cm}^{-1}\left(10^{-5} \mathrm{~N} \mathrm{~m}^{-1}\right)$, using the simplest of materials: a brass trough, waxed glass strips, phosphor bronze wire, a glass pipette, an optical lever and a ruler. Another eminent surface chemist has aptly described this as "measuring molecules with a metre stick". During the 1920 s and early 1930 s he was responsible for a long series of Royal Society papers documenting the surface behaviour of a very wide range of amphipathic insoluble monolayers. $\mathrm{He}$ was thus able to explore a new two-dimensional world with its own equations of state, analogous in many ways to three-dimensional solids, liquids and gases, but with some intriguing differences. The extension of this work to biological materials, e.g. sterols, enabled him in 1929, with O. Rosenheim, to provide powerful evidence in favour of the cyclopentenophenanthrene structure of cholesterol, a view further supported by Bernal's X-ray analyses at about the same time. N. K.'s tenure at Sheffield culminated in the appearance of the first edition of The Physics and Chemistry of Surfaces which, besides chronicling the whole subject of insoluble monolayers, dealt with most other aspects of interfacial chemistry and physics.
After Sheffield, he moved to London to work at University College on the then new subject of colloidal electrolytes which later became the basis of modern detergents. During this period he was chiefly concerned with the surface properties of solutions of pure anionic and cationic surface active substances and their relationship to micelle formation. Nevertheless, monolayer studies, particularly of biological materials, such as sterols, oestrogeris, celluloses and proteins, were continued by a succession of students whose names became familiar in the surface chemistry and biology journals. In 1935 he was elected FRS. The second edition of The Physics and Chemistry of Surfaces, which was almost a complete re-write, appeared at the end of the University College period, and he moved to Southampton in the autumn of 1937.

The situation at Southampton, not yet a university, was very different from that at University College, where Donnan had been Head of the Chemistry Department, with Ingold occupying the chair of Organic Chemistry: Freundlich was also there. N. K. found himself Head of a department with two lecturers, one assistant lecturer, two demonstrators and a research assistant occupying premises which included two huts from the 1914-18 war. Within two years war had come again, and although the college escaped with comparatively little damage, the problems of maintaining the department in a city that received so much of the enemy's attention are difficult to overestimate. Nevertheless he took a leading part in the ARP activities, such as fire watching and gas detection, and yet found time to get the third edition of Physics and Chemistry of Surfaces published in 1941. After the war, with the growth in demand for university places, N. K. was preoccupied with planning new accommodation for the Chemistry Department and became more and more involved in college administration leading up to the granting of university status in 1952 . He was Dean of the Faculty of Science for many years, and of this period he wrote that administrative chores were "time consuming, though not always uninterest- ing". Just before his retirement in 1957 , he published a second textbook, Physical Chemistry, written with the same clarity and accuracy that were characteristic of the earlier Physics and Chemistry of Surfaces.

Having detailed, very inadequately, his academic life, one has only told part of the story of this very remarkable man. His dedication to the task in hand, whether it be planning for a new laboratory, preparing a lecture, or adjusting the tappets of his car (which was new in 1934 and lasted almost to the end of his life); his addiction to "do-it-yourself", which extended into the laboratory; his abhorrence of pretension and insincerity; his fiery temper; his sense of fun ; his kindness and sensitivity; his generosity; his love of music; his passion for ducks-all these endeared him to those who enjoyed his friendship and now mourn his passing. His wife, Winifred, whom he married in 1916, and with whom he shared so many of his interests, and their son Arthur, survive him-their daughter Jean (Mrs Adams) died several years ago.

The funeral service, conducted according to the practices of the Church of Christ, Scientist, had a simplicity that was entirely appropriate to everything that N. K. had stood for.

\section{Addendum}

IN the article "Effect of Commensal Hydroids on Hermit Crab Competition in the Littoral Zone of Texas" (Nature, 241,139 ; 1973) by H. O. Wright, the author has informed us that the name of the junior author and the acknowledgments were inadvertently omitted from the revised manuscript. G. A. Matthews should have been listed as junior author and the acknowledgments should have read as follows: "Part of the background work was performed by $\mathbf{S}$. Brunenmeister, C. Shaw and other University of Houston students. We thank C. Hand for suggesting the problem, based on an old personal communication by M. Burkenroad." 